UDC 504.03

DOI https://doi.org/10.37687/2413-7189.2019.4.2

\author{
Wasiuta Sergiusz, \\ Doctor of Philosophical Sciences, Professor \\ of the Pedagogical University of Cracow \\ ORCID: 0000-0003-3402-963X
}

\title{
UKRAINE BEFORE AND AFTER CHERNOBYL: \\ SOCIAL AND MEDICAL AFTERMATH OF THE DISASTER IN CHERNOBYL AS A RESULT OF SOVIET COLONIAL ECOLOGICAL POLICY
}

\section{УКРАЇНА ПЕРЕД ТА ПІСЛЯ ЧОРНОБИЛЮ: СОЦІАЛЬНІ ТА МЕДИЧНІ НАСЛІДКИ КАТАСТРОФИ В ЧОРНОБИЛІ ЯК РЕЗУЛЬТАТ РАДЯНСЬКОЇ КОЛОНІАЛЬНОЇ ЕКОЛОГІЧНОЇ ПОЛІТИКИ}

The scientific article provides a comprehensive analysis of the social and medical consequences of the Chernobyl disaster as a result of Soviet colonial environmental policy. The author draws attention to ignoring the problems of environmental degradation by party bodies of the Soviet Union. The idea that the socialist system of economic planning could not ensure proper environmental management is set. Efforts to improve environmental policy were limited by administrative procedures. The low efficiency of the legal regulation of the rational use of natural resources and environmental protection was due to the declarative nature of the legal norms. It was found that the potential risk for the prospects of an administrative/command economy, which is growing in social and environmental spheres, has stimulated the apparatus to join international environmental cooperation.

It is established that the Chernobyl nuclear accident has drawn attention to issues related to the collection, processing and analysis of data on contamination of a certain area. A scientific discussion was started on the general state of the environment in Ukraine, air, water and soil pollution, the effects on the life and health of the population. Among the most common diseases, the author identifies problems related to the respiratory system, circulatory system and nervous system. There were also disorders of the digestive system, inflammation of anemia of the thyroid gland, tonsillitis, congenital defects of the circulatory system.

It is proved that the main reason for the deterioration of the state of health of the population was the irradiation and pollution. Constant exposure to small doses of radiation that affect the population, as well as a general decrease in living standards, poor quality of food, constant emotional and psychological stress.

Key words: Soviet environmental policy, Chernobyl disaster, radiation, health of the population, social consequences, medical consequences.

У статті проведено комплексний аналіз соціальних та медичних наслідків катастрофи в Чорнобилі внаслідок радянської колоніальної екологічної політики. Автор звертає увагу на ігнорування партійними органами Радянського Союзу проблем погіршення стану навколишнього середовища. Обстоюється ідея, що соціалістична система економічного планування не могла забезпечити належне природокористування. Спроби вдосконалення екологічної політики обмежувались адміністративними проиедурами. Низька ефективність правового регулювання раціонального використання природних ресурсів та охорони довкілля була зумовлена декларативністю правових норм. Встановлено, щзо потенційний ризик для перспектив адміністративної/командної економіки, щчо зростає в сочіальній та екологічній сферах, стимулював апарат приєднатися до міжнародного співробітниитва у галузі охорони навколишнього середовища.

Встановлено, що ядерна аварія в Чорнобилі привернула увагу до питань, щзо стосуються збору, обробки та аналізу даних щцодо забруднення певної території. Було розпочато наукову дискусію щзодо загального стану довкілля в Україні, забруднення повітря, води та грунту, наслідків для життя та здоров'я населення. Серед найбільш поширених захворювань автор виділяє проблеми, щяо стосуються органів дихання, системи кровообігу та нервової системи. Спостерігалися також порушення травної системи, запалення, анемії щитовидної залози, тонзиліт, вроджені вади системи кровообігу.

Доводиться, щуо основною причиною погіршення стану здоров'я населення стало опромінення та забруднення навколишнього середовища. Постійне опромінення малими дозами радіачії впливає на населення, як $i$ загальне зниження рівня життя, низька якість їжі, постійне емочійне та психологічне напруження.

Ключові слова: радянська екологічна політика, Чорнобильська катастрофа, радіачія, здоров'я населення, сочіальні наслідки, медичні наслідки.

Introduction. Ukraine before and after Chernobyl this is a story of introducing pseudo-technocratic policy of Soviet management on Ukraine in 1970 - 1980 and their tragic consequences in the present realities.
Technological era can be characterized by growing anthropological impact on the environment and wasteful exploitation of nature. Increase in energy consumption, consumer oriented, wasteful exploitation 
of natural resources, exacerbated social and ecological opposition. The authorities were trying to resort to various measures in order to stop the deterioration of ecological situation. In 1970-1980s they introduced a number of programmes, which were concerned with the Environmental protection and the natural resources management. Soon the environmental factor became crucial spot in political fights.

The aim of the publication is to investigate the social and medical consequences of the Chernobyl disaster as a result of Soviet colonial environmental policy.

Content. In the second half of 1970 s any economy oriented undertakings had priority over ecologically oriented actions. Increase in production was the main goal and only when devastation of environment became apparent, environment connected matters arose. With such attitude, ecological situation was getting worse, gaining new characteristics and complexity.

Overexploitation of natural resources especially of crude oil and natural gas brought about necessity of importing natural resources from Russia and other republic of the former USSR. Miscalculation in distribution of production centres and misuse of human resources in 1970-80s caused the worsening of demographic situation in cities. The need of reorganization and increase the area of farmlands became evident. However, there was no real assessment of those processes because any predictions were based on mechanical approach to nature and were over optimistic. Nature was seen as inexhaustible source, which is to be exploited. Any other approach to those problems were understood as an expression of bourgeois ideology.

Environmental issues traditionally understood as environmental protection were of some interest to the state-run institutions. Some of established laws were somehow meaningful for the system. However, political half-heartedness was meant to impress citizens and was not backed up by any real actions and the true will of putting law into practise.

Paying no attention to deterioration of environment, party organs of the imperialist centre were trying to pass some resolutions for so called improvement in ecological policies in Ukraine, but they turned to be nothing but administrative procedure. Those documents did not have any significant role in economic undertakings of the country. Rational use of natural resources, stricter control over works connected with environmental protection and improvement in general state of environment were nothing but empty words meant to make political impression.

Towards the end of 1970s Soviet authorities shifted the focus of their ecological policy. They were not able to manage one unified centralized policy for the whole empire and emphasised the importance of management for individual republics and districts. Such decentralization worked to advantage of optimization of social and ecological cooperation because it enabled better understanding of local specificity. In accordance with such trends in 1978 new form of longterm ecological planning came into being. It resulted in territorially complex outlines for environmental protection for individual cities and big industrial centres, for specific districts, regions and unique areas of natural environment. However, lack on money, formalism and irresponsibility ruined this form of ecological planning as well.

The propaganda machine of Soviet totalitarian state was still emphasizing, in official documents, made up stories about advantages of socialistic management of environment over capitalistic one. There was a wide spread belief in peaceful coexistence of socialistic society and environment. In ideology of those days socialized, nationalized nature was presented as easy solution to any contradictions, which might come up. Issues connected with misuse of environment such as distortions of scientific theories were not publically talked about, only some minor mistakes in the utilization of environment were mentioned. In those days environmental protection was seen as a minor matter, which can be easily solved by use of limited means. The connection of environmental problems and technology, defective organization of production processes, the irrational distribution industrial centres and faults in global planning were ignored.

On state level the ecological sector was wholly controlled by party organs. In reality, the ecological policy was up to competences and interest of party apparatus and its leaders. As a result of that some actions undertaken for the sake of environment were not based of any theoretical premises nor recommended by scientists. Unless they agreed with ideological vision of party apparatus, actions meant to help environment were always turned down, and not even taken under consideration. Deformation of the totalitarian society unable undertaking of any effective actions in environmental protection, any attempts turned down to be ineffective because of extraeconomic character of those attempts. Interference in environment were beyond the public control. This situation called for use of more radical means in environmental protection.

In spite of the growing work expenses and increasing environmental expenditure, establishing legal instruments of various rank, which were aiming at environmental protection, the real state of environment in Ukraine in 1970s was sill deteriorating. Up to 1976 offices responsible for statistical data were not gathering and working on any information about the state of environment, this unable taking any steps to change the situation.

Both technical and economic grounds for distribution of nuclear reactors built in 1950s, and construction of industrial sites in the second half of 1970s and first half of 1980s were not taking into account impact on the natural environment. This led to making ungrounded decisions in the sphere of development and distribution of means of production. Evaluation on natural conditions for such undertakings was at that times just beginning its development. In this sphere individual interests of particular groups of party organs were predominant, that is why the number of new industrial plants was increasing 
without the increase of undertakings connected with environmental protection and building of new sewage treatment plants. Some of already existing protective works were damaged or did not work efficiently. Assessment of industrial activities of individual plants did not take into account its impact on environment, which took off them the burden of financial and legal responsibility and unable the rational planning of utilization of environment. Additionally local authorities concerned with economics did not have enough competences and units occupied with environmental protection. Legislation concerned with environmental protection of that time did not have legal instruments ready, which limited use of any sanctions for those who break the law. Departments, which were controlling the state of environment, in 1976 employed 3 thousand office workers, were divided but they did not stood a chance of carrying out effective work in environmental protection. The State Environmental Council of Ministers of the USSR was very limited in its competences. But despite those limitations, having analysed various aspects of utilization of nature in Ukraine it was bringing in many proposals to The Council of Ministers of the USSR to the ministers themselves and departments and most of them was accepted. In the 1981 the USSR Act "About the protection and use of fauna" was passes, it came into force on 1 March 1982. It stated that the animal world is the public property, but it did not guaranteed any real protection.

Potential hazard to prospects of administrative/ command economics, which was increasing in the social and ecological spheres, stimulated the apparatus to join international cooperation in the field of environmental protection. In 1981-1985s delegation from USSR attended meeting of UNEPUnited Nations Environmental Protection. In Kiev international discussion on matters of global monitoring of soil was held as a part of one of UNEP projects. Ukraine was continuing its work as a part of "Human and the biosphere" programme, which started in 1973 and in 1984 became the member of the International System of Information about Environment (INFOTERRA). But all those attempts could not keep the pace with the increasing ecological crisis.

Economical crisis at the beginning of 1980s drew the attention of authorities away from the ecological issues. In the mid 1980s new Soviet and party executive, which in April 1985 started "perestroika" and supported so called socialism with a human face, was forced to acknowledge the deteriorating condition of natural environment in all republics of the Soviet empire. It advanced the thesis that there were some major mistakes and perversions in former environmental policy and actions connected with environmental protection.

In July 1985 subsequent session of The Supreme Council of the USSR was held where resolution titled: "Meeting law requirements in environmental protection and rational management of natural resources" was established. But realization of this resolution was oriented exclusively on administrative/command system methods of management and motivation was grossly based on means beyond economics. This document was only a political illusion, it propagated the need of further economic growth, the need to tighten the control over pollutants, the need to increase the effectiveness of local peoples' councils, improvement of co-operation between economic and monitoring organs in the undertaking of actions connected with the preservation of nature.

Formal mobilization of, in most cases, only sociopolitical activity in the sphere of ecological policy could not compensate for the lack of investments, and accurately drawn up legislative documents or the plain responsibility for the entrusted matter of the future on nature and our descendants. The crisis of command economy, which began at the beginning of 1980s and determined the inauspicious attempts of the Gorbachov's "perestroika" in the second half of this decade caused the deepening of the crisis in the ecological situation in the Ukraine.

During the penultimate party's convention in 1986 the issue of worsening state of natural environment in some regions of the country was brought up. According to the Central Committee of the Communist Party, such situation was a direct result of delays in the utilization of academic and technical achievements concerned with protection of natural environment, completion of investments in the out dated technology, and introduction of poor technologies. At the same time new party's manifesto groundlessly stated, that the realization of the previous manifesto improved the condition of nature and introduced regulations concerned with its use. Those intentional distortions make the Central Committee of the Communist Party and its so called "republic squad" Communist Party of Ukraine the main culprit of deterioration of the naturals environment in Ukraine.

Increasing openness and growing democratic trends brought up by Gorbachov's "perestroika" by the end of 1980 s, made possible more realistic assumption of the entire load of stagnation and deformations of the past. Such conception of the past was introduced on XIX General Party Convention in 1988 it made clear that there is a real danger of ecological disaster and provoked a discussion on its political social and economic causes. When the political existence of Communist Party of the Soviet Union (CPSU) was drawing to a close, when democratically oriented communists and Bolshevik orthodox were fighting with each other during the last XXVIII party convention of the CPSU it was finally admitted that socialistic society is also capable of wasting and abusing the environment. It was announced in the manifesto titled "Towards humanistic democratic socialism". For lack of such openness, covered by ideological camouflage, Ukraine and other nations of former UCCR paid very high price.

Ecological and socio-economic limits of totalitarian administrative/command system were clearly seen in the development of nuclear power technology. According to the UCCR plans of nuclear energy development, there were 9 nuclear power stations to be built in Ukraine. Realization of those plans began in 1977 when the first unit of Chernobyl power station was put into 
operation. From 1976 to 198916 more units with the total power of $14800 \mathrm{MW}$ were put into operation in 5 nuclear power plants - Zaporoskej, PołudniowoUkraińkiej, Roweńskej, Chmilnickej, Chernobylskej. Plans for setting up of Czehryńskiej and Charkowskiej nuclear power plants were never realized due to major geological mistakes in choosing their locations. The nuclear accident in Chernobyl nuclear power station on 26th April 1986 was a tragic consequence of soviet technocratic short-sighted policy. It was a consequence of socio-economic stagnation in the period 1960-70. Due to total censorship news about nuclear accident could not reach the publicity. The truth about the accident had to overcome many difficulties before it could be revealed in newspapers, radio or on TV.

Nuclear accident in Chernobyl turned the public against the policy of "Peaceful utilization of atom" and changed the plans of soviet nuclear departments. In may 1987 stopped construction of two new units in Chernobyl nuclear power station. Giving in the public protests cancelled the commission of building Odeska nuclear power station. In October 1989 two nuclear reactors in Krymska nuclear power station, which at that time were ready to put into operation, were transformed.

Socialist system of economic planning could not assure proper utilization of nature. Regulations were not improved or observed, any data about the pollution and real state of environment were treated as a classified information. This further hindered realization of any ecological policy. Borys Olijnyk during the I Convention of Public Deputies of UCCR in 1989 bitterly criticised the colonial ecological policy in Ukraine: "Central departments put into operation nuclear power stations, giant chemical plants as they please. But those doubtful gifts are located in historical and cultural centres such as Kijów, Kaniów, Zaporoże, Równe, Chmielnicki and those "bombs" are planted in those sanctuaries of our nation against entire republic. The fight against those industrial invaders should become our priority".

By the end of 1980s the difficulties connected with repair of damages caused by the Chernobyl disaster further complicated ecological situation of the republic. It affected all aspects of public life. Actions undertaken for repair of those damages proved to be insufficient. In the contaminated regions the socio-political situation was very tense. As a result of contradictory opinions of scientists and experts many essential safety procedures were stopped and public felt that their trust has been betrayed by local and central authorities. In the 1990 the long-term republic programme of reparation of damages of the nuclear accident hasn't been drawn up yet. Such a long time, which took to prepare this programme, provoked public mistrust. At that time, there was still no full and detailed information about the scale of contamination. Thousands of people living in the contaminated area were waiting to be resettled. Such situation was a result of many shortcomings on all levels of soviet-communist administration. Among those shortcomings we can list: insufficient coordination of undertaken actions, keeping the true data about the level of contamination a secret, wrong and unconvincing announcing the news to the public, lack of special organ responsible of handling the entire situation. Soviet administrative system proved to be deficient in many ways and was absolutely impotent in handling legislative, scientific, social, psychological and other aspects of this extremely difficult situation. The authorities of the state were completely crushed by the large scale of the disaster, which happened so near the capitol and by indeterminacy of the reactions, which were undergoing inside the wrecked nuclear reactor. They were financially dependent on the central budget and therefore could not independently react to the catastrophe. It was not but four years later when the Supreme Council of the UCCR passed the following motion "The programme of repair of damages caused by contamination after the nuclear accident in Chernobyl nuclear power station and its aftermaths". The document anticipated the period 19901992 for taking some actions for repair of damages caused by the accident. It tried to work out methods of lowering the level of contamination and a draw up system of concessions and compensations for damage of health as well as a system of radioecological information accessible for public.

Over the years the true consequences of nuclear accident proved to be worse than expected. Under pressure of foreign and internal public XXVII convention of Communist Party of the Soviet Union passed the resolution "About the political assessment of nuclear power accident in Chernobyl and course of actions taken after repair of the damages". Let me quote some statements from this document: "We, delegates.... being fully aware of the situation and share the pain with millions of people from Belarus, Ukraine, Soviet Union, which suffered as a result of the accident. In the administrative/command system executive allowed for some scientific and technical mistakes in the field of nuclear energy and radiation defence of citizens in case of accidents. The Ministry of Power Industry, Ministry of Health, State Board of Nuclear Energy, Academy of Sciences, civil defence of the UCCR proved to be incapable of protecting our lives and health and not ready to employing proper means... Conceit and irresponsibility of some scientists, ministers, department managers responsible for construction and utilization of nuclear energy stations, their groundless safety guarantees, led to lack of country's policy for handling critical situations. Our Convention states that Political bureau of Central Committee of CPSU, Council of Ministers of CPSU, Central Committee of Communist Party of Ukraine and Belarus, Councils of Ministers of the USRR and the BSRR misjudged the scale and aftermaths of the disaster and did not take proper actions to protect people from contaminated regions".

At that time such resolution was construed as progressive but rather belated. Again the sovietcommunist system was trying to elude true political and socio-economical causes of Chernobyl accident. It didn't admit to the truth about extensive, unhumanistic, technocratic way of ruling the country. 
Over the years it became evident that documents concerning proceedings in case of nuclear accident, which were legally binding in all Soviet Union as well as those binding only in Ukraine, were flawed, did not protect people, did not specify any official body responsible for coordination of undertaken actions. There was an urgent need for new legal document, which would state the procedures how to minimize the impact of Chernobyl accident on people's health, environment, enabled conducting scientific research in contaminated regions. Therefore before announcing the independence of Ukraine the Supreme Council of UCCR in March 1991 enacted project on distribution of people living in the contaminated regions and new laws "The legal regime for regions which were contaminated as a result of Chernobyl catastrophe" and "Status and welfare of citizens, affected by the nuclear accident in Chernobyl". According to those laws the contaminated regions has been divided into following zones: distance zone (2 regions, 70 towns), compulsory displacement zone (5 regions, 92 towns), voluntary guaranteed displacement zone (7 regions, 786 towns), zone of intensive contamination monitoring (10 regions, 1226 towns). All contaminated zones as counted in 1991 covered 2180 towns and population of 2576 thousands. Research on constant radiation monitoring, shows that the contaminated area is going to enlarge over years to come. Deep economical crisis, security system insufficient financially and technically, lots of wasted time since catastrophe are among factors, which worsen socio-economical situation, hinder any improvements in the condition of environment and for the people of Ukraine.

The nuclear accident in Chernobyl draw attention to issues concerning gathering, processing and analysing data on contamination of a given area. Scientists started to debate on general condition of environment in Ukraine, percentage contamination of air, water and soil. But still there was no unified monitoring system for the whole Ukraine. There were individual monitoring systems in some departments like: State Nature Committee, State Agricultural Committee, but they did not develop unified methods and coordination of their work.

By the end of 1980s the need for changes in management in the field of environmental protection became evident. At the end of its existence, totalitarian soviet system called for radical changes.

By the end of second half of 1970-80s real situation in Ukraine deprived of political and economic independence was really difficult. Some incompetent decisions on projects harmful for environment could be made covered by unrestricted power of communist party. Policy of production with no limits, industry subordinated to militarization had insufficient founds for solving environmental problems. Ideologization of public life and self-contained society made it impossible for public to learn about the true condition of environment. The economic development was based on extensive use of environment and natural resources. The environment as a public property, in fact was entirely controlled by the Communist party apparatus.
Republican departments and offices transformed into transnational monopolies, which did not show any respect for public welfare and nature requirements. At that time many harmful for environment industrial investments were approved and constructed. The chemical and heavy industries were in the lead. Locations for nuclear power units were chosen without taking into account unfavourable environmental and geographical conditions. The main premises and goals of development of ecological policy in Ukraine at the end of 80s were political and financial independence, democratization of public life and gradual transformation towards free market economy.

The biggest known technological catastrophe was a direct cause of major socio-economical and medical changes. After the accident, as it is known, official authorities classified all information about its perspective results including the medical ones. Data about cases of illness, results of treatment, level of irradiation, data about the contamination of the region, and about the loss of working abilities were all classified information. According to the former Minister of Health Care, the law about classification of information caused a lot of harm, especially because it was kept a secret from the people of their mother nation. Despite the fact that the foreign specialists quickly discovered the truth, the authorities not only did not allow the doctors to tell the truth, but they forbade connecting the cases of illness with the contamination.

Possibility of realistic assessment of the scale, character and level of contamination came out in 1991, when the approach towards protection against radiation hazards changed.

In 1987 the government of Ukraine prepared and handed over to Soviet governing body the programme for the struggle with the aftermaths of the Chernobyl accident. But bureaucracy, and the policy to keep silence and diminish size of the disaster, did not allow to put the program fully into practice. The worsening socioeconomical situation did not absolve local governments of responsibility of dealing with the aftermaths of the disaster taken in 1990. In the case of nuclear catastrophe, the number of casualties is increasing over time, that differentiate it from other technological disasters. In 1986 31 dead and 237 suffering of radiation sickness were counted. In 1992 according to data from "'Chernobyl company" ("Spółka Czarnobla") there were 7 thousand dead and 50 thousand suffering of radiation disease among those affected by the accident. "We can trust or doubt this data, - emphasized in 1991 on International Conference "Eurochernobyl-2" Ju.M. Szczerbak, - but official health care authorities refrain from comments of this subject, not confirming and not turning them down".

Among medical aftermaths of the accident, we can distinguish deterioration of the general state of health, thyroiditis - especially common among children, various illnesses of blood and blood circulation system, Vegetaive-vascular dystonia, and symptoms of immunological deficit so called "Chernobyl AIDS". 4 million of citizens, who inhabited contaminated regions 
of Ukraine, Belarus and Russia, observed worsening of their mental state and increase of socio- psychological tension.

According to doctor D. Goffman (USA) the fatality of the Chernobyl accident will reach $1 \mathrm{mln}$. Or 3840 per $1 \mathrm{mln}$ people-ber. "If such thing really happen, - emphasized academic D. Grodzinśkij at his speech in 1991 at the conference "Euroczarnobyl-2", such number of unexpected deaths will not be noticed in Europe, because the contamination spread over such a vast territory over national frontiers. Some people state that it is not so drastic, because the true number will become known if 50-70 years. But this is amoral way of thinking. We can not assess the scale of human tragedy with the same measure we use in the animal world".

In contaminated regions increased the total number of illnesses including the oncological ones, mortality among children, and number of congenital defects. Research, conducted on animals, which at the time of nuclear accident were within the distance of $30 \mathrm{~km}$, confirmed that contamination causes changes in blood, immune system, blood circulation system and other. Results of testing of population from contaminated regions become more alarming with time. Small dozes of radiation acquired over long period of time weaken the immune system. Nowadays radio biologists are inclined to believe that there is no smallest dose of radiation, which is absolutely safe for human. Conducted experiments prove that genetic changes happen even at low level of radiation. In nature mutation on low level can have positive results, because it leads to diversity of forms. It is different in the case of human being. Every change caused by mutation has tragic consequences. Human can get used to higher doses of radiation, but over long period of time as a part of evolution processes. Other cause of concern is that radiation cumulates in organism. Authorises calculated maximum acceptable doses considering caesium only. Not until recently, they started to include radioactive isotopes of strontium, plutonium, cerium, ruthenium, oxides of many metals, leftovers of nuclear fuel, carbon molecules and so on.

In contaminated regions was observed very high level of diseases such as: respiratory track diseases, the alimentary canal diseases, diseases of endocrinology system, immune system, psychological disturbances, diseases of blood circulation system, pregnancy complications, and some anomalies. Very alarming is increase in number of inflammation of thyroid cases among children. Scientists explain the increase of cases of diseases as due to genetic changes it can reach $50-100 \%$. The fact of increase in the total number of observed diseases, genetic and oncological pathologies is undeniable.

For those who know, what is radiation - "35-ber concept" is a genocide, crime against the mankind. Natural radiation, which is received by people throughout their lives is not taken into account. 0.5 ber, which should be received by person in the year, was calculated only taking into account caesium, 200 or 300 other elements, which produce radiation alpha and beta were ignored. Radiation gamma consist only 5 to $7 \%$ in the total internal and external radiation. If we include all other radioactive elements into our calculation we can see, that person throughout his life is to receive 700 ber rather than 35. The goal of such lie was, according to L.P Kindzelski, to prove that the accident in Chernobyl was not at all as serious as it was thought. It was meant to convince people that central nuclear management was not to be blamed for this accident, and it did not have to pay the compensations. According to it, radiation and increase in the number of diseases, had nothing to do with each other.

In the majority of so called developed countries the acceptable radiation limit it $1 \mathrm{mSv}$ per year or $1 / 10 \mathrm{ber}$ per year. So in 70 years this 35 ber limit is going to be 5 times above the world standard. According to American standards 10 ber - is the highest acceptable limit to which can person be exposed in his lifetime, for thyroid alone it is no more then 30 ber. However, in the first few days after the accident people who lived in the countryside in the vicinity and drank a litre of milk alone could take thyroid dose of 150 ber. In the mid 1989 the Ukraine scientists examined 14 thousand children to find out that most of them took the dose of 100 ber. But it is worth noticing that Ukraine limits did not take into account the increase of migration of radioactive elements in soil, and the increase of total amount of radiation after eating contaminated food and drinking contaminated water. Milk is one of the most important components of daily diet, it consist $80 \%$ of radiation dose, $10 \%$ depends on outer radiation background. In 1988-1989 the research showed that in diary products norms were exceeded. Is some countryside regions doses accumulated from food reached 10 ber a year. Most children suffered of tiredness, sleepiness and most of them could be diagnosed with inflammation of thyroid and anaemia diseases connected with the contamination.

Among the many medical problems caused by the nuclear accident in Chernobyl power station, doctors were the most concerned with effects of exposure to radiation. The group with the highest risk consists of children and people who were employed at Chernobyl in April and May 1986. The strongest affected were children who were conceived and has not been born yet, especially at the stage where their brain and thyroid are developed, radiation could cause mental retardation, and other mental and nervous disturbances. Quoting data from the Ministry of Health Care, in 1987-1988 47\% of adults and $53 \%$ of children from the contaminated region were considered healthy, in 1990-1993 those factors worsened - only $32-28 \%$ of adult and $27-31 \%$ of children were still relatively healthy.

Among most common diseases, we find problems concerning respiratory organs, blood circulation system and nervous system. Digestive system abnormalities, inflammation of thyroid anaemia, tonsillitis, congenital defects of circulation system were also observed. Adaptive abilities of young child's organisms have been significantly reduces.

According to data from endocrinological unit of Ukraine scientific research center (UNCRM) AMN 
Ukraine, since 1989, there has been a steady increase of cancer related thyroid abnormalities among children. Compared with the period preceding the accident the number of observed thyroid disorders in 1987-1999 has increased 10 times, especially in Kiev district, Chernigowski, Roweński, Żhytomerski district, where in 1981-1985 were no cases of thyroid cancer among children. In the period 1986-1999 1217 people, who at the time of accident were children had been operated on. Undertaken research has proved that thyroid cancer is twice as often observed among people, living in the contaminated part of Ukraine and six times as often observed in those from the evacuated region than in other parts of Ukraine. Cases of cancer among those who repaired the damages after the accident is three times greater than the average number of observed cases. Nowadays all thyroid disorders emerged. No wonder the programme "Thyroid" was announced the most important subject in International Chernobyl Programme.

Estimating the total dose of radiation from Chernobyl accident, which Ukraine citizens receive from contaminated environment, American scientist Goffman assessed that there will be around 900 thousand of cancer cases. His assessments did not take into account the dose from strontium-90, transuranic and other rare radioactive elements. He totally omitted cases of cancer caused by weakening of immunological system and cases of thyroid disorders, which still could emerge in the future.

There have been more cases of complicated pregnancy, congenital defects, quantitative changes in blood components, weakening of immunological system. Observed cases of diseases among people, who repaired the damages took often unusual course. Especially the cases of cardiomyopathy, hypertonia, dermatological diseases, lungs disorders and digestive tract abnormalities.

Statistically there has been increase in observed cases of different diseases in all $30 \mathrm{~km}$ zone surrounding the place of accident. Especially in Iwanowki district of Kyiv region, the blood samples and organs form circulation system were the most affected. In 1989 there were 2.3 cases of diseases in examined 1000, but in 1990 there were respectively 64.8 cases so it went up 28 times. In examined group of children, under 14 form those regions the disorders of circulation system increased form 1.8 to 21.9 cases. There was a sharp increase in the noted cases of thyroid disorders, urinary tract disorder, and various problems with organs from digestive track, cases of bronchitis and other.

We can compare this data to data from nuclear unit in Sellafield (Windscale, England) published in 1991 in British medical magazine. In 1957 there was s accident, which has been scrupulously examined as far as people's health is concerned. Analysis of anemia cases give following results. Compared to other monitored groups, among children from Sellafield area noted more cases of diseases, especially among those whose parents were employed in the nuclear unit. The risk of having anemia was 2.5 times greater for children, whose mothers worked in the nuclear unit while being pregnant, and 6.5 times greater for children whose parent were irradiated with dose of 10 ber and more before they got pregnant.

For over three years the truth about the Chernobyl catastrophe has been hidden as classified information. For five years since the catastrophe non of the members of Republic's authorities found time to visit the area of strict radiation control. How does the future of children who pay for the mistakes of totalitarian system is going to look like? In period 1991-1992 the research centre "ENDO-polimed" has thoroughly examined (by psychologist, psychiatrist, neuropathologist, pediatrician, endocrinologist) 47 children from Przypiać, whose pregnant mothers were exposed to radiation and 100 children at the same age form Kyiv. Additional tests consisted of general blood tests, assessment of immune system, thyroid hormones content in blood. The results of psychological examination showed that level of general psychical function was below the average. The highest percentage of children with different psychical deviations was noted in Przypiać (72.7\%) but in Kyiv it was also quite high (52.71\%) neuropathological deviations were found in 38.8\% in Przypiać and 51.5\% in Kyiv. The data is similar when we consider somatic pathologies. Especially alimentary canal abnormalities (children in Przypiać - 51.5\%, children in Kyiv - 84.1\%) respiratory track abnormalities (respectively $61.7 \%$ and $52.5 \%$ ) blood circulation system disorders (respectively $8.8 \%$ and $8.9 \%$ ). Major changes in immune system of examined children indicate the low resistance to bacteria and virus.

Cancer specialists claim that in the first five years the number of cancer cases should not increase. But since 1990 and up there will be increase in number of cancer cases. Contrary to what was told the number of leukaemia cases, thyroid cancer, and cases of cancer already cured became more complicated went up in first years after the nuclear accident. Not all noted cancer cases were due to Chernobyl disaster, but the catastrophe activated them. According to data from doctor prof. B.T. Bilynśki, radiation of $1 \mathrm{ber} / \mathrm{mln}$ people or $0.4 \mathrm{ber} / 500$ thousand gives the increase of 200 additional cases of cancer. As you can see not the acquired dose is the most important but the irradiation itself. If there is radioactive element in bone structure or muscular tissue, which can be irradiated by alpha or beta radiation it destroys structure of neighbouring tissues. In 10 years, according to experts, there is going to be higher potential hazard of lethal diseases such as sarcoma. Whole population of Ukraine was exposed to the most dangerous alpha and beta radiation, which cause internal irradiation.

Geography of damages caused by Chernobyl is not restricted to a few districts, and cancer in not only caused by irradiation. For example at the end of $80 \mathrm{~s}$ and at the beginning of 90 in Lviv district, every year 230 people suffering of cancer were registered, the whole population is 100 thousand. This factor is increasing. Industrial pollutants heighten the effects of irradiation, causes the increase of abnormalities connected with genetic mutation. 
In time the damage became apparent, the actions undertaken by the Soviet and Republican authorises proved to be ineffective. After working out what actions should be taken by state and business organ, giving the instructions for self-government, directors of companies and organization The Supreme Council of Ukraine noticed that a lot of time has been wasted. And the health condition of citizens still deteriorates.

The Supreme Council of Ukraine examined arable farms from contaminated regions. It found that in 1990, farms produced 14.7 thousand ton of milk, 62 ton of meat in which the content of reactive elements exceeded the limits. In first five years after the accident the Ministry of Health Care of the USSR and the Centre of Radiation Medicine of USSR did not specify instructions for treating people from contaminated region. It was the minimal work, which should have been done even before 1986.

Situation after Chernobyl created mistrust towards authorities and medical institutions. There were too many conflicts of interests, negligence, mistakes and simple lies in official reports given by "reliable sources". Up till now citizens are not well informed about the aftermaths of the nuclear disaster. Scientific institutions such as the Academy of Science and the Ministry of Health Care did not provide necessary medical information and appropriate preventive medical help. All this contributed and summed up with negative demographic and medical trends. In the Roweński region, the number of congenital defects increases three times, infant mortality - two times. There were more noted cases of anaemia, inflammation of respiratory organs, hepatitis, and other.

Eight expert committees were employed to determine the relation of those cases of illness to the nuclear accident in Chernobyl. Scientists, after examining more then 500 cases from contaminate regions, decided that almost $90 \%$ of them are directly related to the irradiation. In 1990 noticed 65795 cases of diseases, and 4365 deaths connected with works on repair of damages after the accident and in 1998 - respectively 6052 and 789. Every 5 ber causes increase in observed mutations by $0.5 \%$. The scientists once more emphasized that "35-ber thesis" is ungrounded because there really is linear relation the smaller dose the smaller effect, but the effect is never nil but only relatively smaller. For example, in $1 \mathrm{mln}$ people irradiated with dose 1 ber, there are 50347 additional cases of abnormalities caused by mutation to be expected. It is worth noticing that "Chernobyl" overlaps with difficult ecological situation in Ukraine. For example in Dniepropietrowskie region industrial pollutants at the beginning of $90 \mathrm{~s}$, determined that the level of mutation was higher then in irradiated monitored regions.

Medicine research institutes in Kyiv and Lviv detected accumulated cytogenetic effects even with small radiation doses. So, consequences of Chernobyl are to be felt even in years to come. Even at the beginning of 90s there were still insufficient supply of food free of contamination to the regions which suffered as the result of irradiation. The directives of the Minister of Health Care concerning the food supplies where not carried out.
In time the consequences of the Chernobyl accident became more and more evident. It is due to data gathered in scientific research and to more detailed monitoring of irradiated regions. Concepts and criteria of assessing the aftermaths of the accident were drew up in new law.

Lately we can observe increase in cases of various diseases and dysfunctions among pregnant women. Firstly, it is the kidney failure, the increase if from $12 \%$ to $51 \%$, the number of blood circulation system failures increase from $19 \%$ to $63 \%$. Among problems with blood circulation system the most important is dystonia over $59.5 \%$, hypertonia $-18.3 \%$, rheumatism $-18 \%$, other failures $-4.2 \%$. There is some research on pregnancy complications, among women from contaminated regions.

Among failures of endocrinological system the average factor of cases has been exceeded 10-15 time. It includes thyroiditis (10 times over the average), diabetes. Among people who were employed for removal of the damages, the problems with blood circulation system (hypertonia, cardiomyopathy) also exceed their average number for population of Ukraine $(256.1 \%, 115.4 \%$ against $69.3 \%$ and $33.2 \%$, which are the average for Ukraine). The index of disability in 1988 was $2.6 \%$ for men and $2.5 \%$ for women employed for removal of the damages. In 1990 it increased to $12.4 \%$ and $12.1 \%$ and in 1991 after correction the criteria of assessing the disability it reached $34.8 \%$ for men and $60.7 \%$ for women, which can be caused not only by worsening heath conditions but also socio-psychological factors.

The mortality rate once more stresses the poor health conditions, despite relatively young age of people who were employed for removal of the damages $(25-$ 45 years), the mortality rate increases every year by $2.26 \%$ in 1988 it was $10.05 \%$ and in 1998 the mortality among people in economically productive age increased by $60 \%$. The similar trends can be observed among other groups of casualties (evacuated people and people who still live in the contaminated region).

The total number of fatalities among people who suffered as a result of the Chernobyl disaster in the period of 1993 to 1988 exceeds 90 thousand people.

Nowadays the group of a higher risk expanded to include children who were born after the accident to parents affected by the disaster. The category of those who need special medical attention belong 700 thousand children from Kyiv, Zhytomerskie, Czernigowskie, Wołyńskie, Roweńskie, Winnickie, Czerkaskie, IwanoFrankowskie, Czernowieckie, Ternopolskie and those children who were evacuated, and resettled. In this group there has been 772 cases of thyroid cancer (40 cases in 1996), 782 children were categorized as disabled people, as a result of the Chernobyl accident. From 1997, 1998 there is also some research on congenital defects, the number of those cases increased to $13 \%$.

Since 1987 there is increase in number and wider spread of all kinds of diseases. In 1996 the number of cases of malignant tumor among adults and teenager increased more then 2 times in comparison with 1987. That includes the thyroid cancer, cases of which are 2.5 times more common than in 1989 (there is no previous 
data) it exceed by over 43.9 the average for Ukraine. The spread of lethal cancer related changes in lymphatic system and blood increased 2.2 times in 1987. Cases of malignant tumor in digestive tract and respiratory system count up to $34.4 \%$ and $16.5 \%$ respectively.

The main cause of deterioration in heath condition according to experts is the accumulation of irradiation and the environmental pollution. The continuous exposure to small doses of radiation which affect the population of this region, and other harsh conditions such us worsening of general living condition, poor food quality, and constant emotional and psychological tension all have their impact.

Conclusions. From the accident we can learn a lesson that in the world of new technologies people have to adjust their outlook on life and create a new scale of importance. Health protection, right to basic social and ecologic standards of live should be given a priority. Mankind should be responsible for protection of environment and its defensive strengths. The responsibility grows with constant development of new technologies, and with diminishing natural resources. New technologies which enable us to solve socioeconomical problems with lower expenditure of natural resources create additional responsibility connected with its use. Nowadays mankind enters a new stage of development of our civilization, only mutual political support, sharing of scientific and technical information is likely to assure proper protection against aftermaths of industrial disasters.

\section{References:}

1. Tichonowa N.E Reszenie ekologiczeskich problem w SSSR: istoria i sowremennosć. Moskva : Znanie, 1989. s. 23.

2. Konsytucja (Osnawnyj Zakon) SRSR. Kyiv,1982. S. 8, 10, 20

3. Ochrana okryżajuszczej sredy: uprawlenie, prawo. Kyiv : Naukowa dumka, 1982. S. 17, 321-325.

4. Istoryko-geograficzne wywczennia pryrodnych ta socialno-ekonomicznych procesiw na Ukraini : Zbirnyk naukowych prać. Kyiv : Naukowa dumka, 1988. S. 25; Ochrana okryżajuszczej sredy: uprawlenie, prawo. Kyiv : Naukowa dumka, 1982. S. 324.

5. Tichonowa N.E. Reszenie ekologiczeskich problem w SSSR: istoria i sowremennosć. Moskva : Znanie, 1989. S. 31.

6. Archiw Minekobezpeky Ukrainy, f. 4778, op. 1, spr. 395. Ark. 38-39.

7. Malyszewa N. Znaty, poważaty, wdoskonaluwaty zakon. Ridna pryroda. 1990. No 4.

8. Ridna pryroda. 1982. No 3.

9. Archiw Minekobezpeky Ukrainy, f. 4778, op. 1, spr. 720. Ark. 2-3.

10. Ochrana prirody - zadacza wsenarodnaja. Kyiv,1987. S. 13.

11. O sobludienii trebowanij zaconodatelstwa ob. Ochronie prirody i racionalnom rspolzowanii prirodnych resursow: Postanowlenie Wierchownogo Sowieta SSSR ot 3 ijula 1985g. Ob. Ochronie okrużajuszcziej sredy: Sbornik dokumientow partii i prawitelstwa. 1917-1985 gg. S. 389-395. 